\title{
Rooting Response of Azalea Cultivars to Hot Water Treatment Used for Pathogen Control
}

\author{
Warren E. Copes ${ }^{1,3}$ \\ USDA-ARS Thad Cochran Southern Horticultural Laboratory, Poplarville, \\ MS 39470
}

\author{
Eugene K. Blythe ${ }^{2}$ \\ Coastal Research and Extension Center, Mississippi State University, South \\ Mississippi Branch Experiment Station, Poplarville, MS 39470
}

Additional index words. azalea web blight, cutting propagation, Rhizoctonia, sanitation, thermotherapy

\begin{abstract}
Submerging terminal leafy cuttings of Rhododendron L. 'Gumpo White' ('Gumpo White' azalea) in $50{ }^{\circ} \mathrm{C}$ water for $21 \mathrm{~min}$ was previously shown to eliminate binucleate Rhizoctonia species, the cause of azalea web blight, from plant tissues. Before considering commercial use of this practice, a better understanding of the rooting response and tissue sensitivity of evergreen azalea cultivars to $50^{\circ} \mathrm{C}$ water was needed; therefore, the current study was conducted. Terminal cuttings of the azalea cultivars Conleb (Autumn Embers), Fashion, Formosa, Gumpo White, Hardy Gardenia, Hershey Red, Macrantha Pink, Midnight Flare, Red Ruffles, Renee Michelle, Roblel (Autumn Debutante), and Watchet were collected and submerged or not submerged in $50^{\circ} \mathrm{C}$ water for $20 \mathrm{~min}$ before propagation in one experiment. All 12 cultivars tolerated $50^{\circ} \mathrm{C}$ water for $20 \mathrm{~min}$. Cuttings collected from the 12 cultivars were submerged in $50^{\circ} \mathrm{C}$ water for $20,40,60$, and $80 \mathrm{~min}$ in a second experiment. The cultivars varied in sensitivity when exposed to $50{ }^{\circ} \mathrm{C}$ water for 60 to $80 \mathrm{~min}$ resulting in differing responses in root development and final leaf count. In a third experiment, degrees of leaf damage caused by hot water submersion or by leaf removal were evaluated for the effect on root development and subsequent leaf count on rooted cuttings of 'Gumpo White' and 'Roblel'. Induced incremental increases in leaf damage from hot water resulted in incremental reductions in the final leaf count and extent of root development for 'Gumpo White' and 'Roblel' while increasing percentage of leaf removal caused no reduction until $75 \%$ or greater leaf area was removed. Despite the risk imposed by submersing azalea cuttings in $50^{\circ} \mathrm{C}$ water, all 12 azalea cultivars were tolerant of submersion durations long enough to eliminate binucleate Rhizoctonia species from stem and leaf tissue with only a low likelihood of sustaining detrimental damage.
\end{abstract}

Azalea web blight, caused by certain binucleate species of Rhizoctonia, occurs yearly on some azalea cultivars during nursery production in the southern and eastern United States. Azalea shoots collected for stem cutting propagation can harbor the pathogen, thus allowing the disease to be perpetuated through vegetative propagation. A previous study demonstrated that submerging Rhizoctonia-infested stem pieces of 'Gumpo White' azalea in $50{ }^{\circ} \mathrm{C}$ water for $21 \mathrm{~min}$ could eliminate the pathogen without causing significant damage to leaf tissue (Copes and Blythe, 2009). Because the objective of the study was pathogen control

Received for publication 13 Oct. 2010. Accepted for publication 5 Nov. 2010.

Our thanks to Martin's Nursery, Semmes, AL, and Flowerwood Nursery, Inc., Mobile, AL, for donating the stock plants used in this study. We acknowledge Lavonne Stringer and Whitney Sumpter who collected, processed, and assessed damage and growth of cuttings.

${ }^{1}$ Research Plant Pathologist.

${ }^{2}$ Assistant Research Professor.

${ }^{3}$ To whom reprint requests should be addressed; e-mailwarren.copes@ars.usda.gov. efficacy, a level of acceptable leaf damage was determined based on reasonable expectations without documenting the effect on root development. In the same study, hot water treatment (HWT) was the only sanitation method found to be effective in eliminating Rhizoctonia anastomosis group-P from azalea stem pieces. Soaking infested stem pieces in selected chemical disinfestants or fungicides was ineffective.

Sanitation is a proven and cost-effective approach for limiting the entry of pathogens into a propagation facility (Daughtrey and Benson, 2005; Williams-Woodward and Jones, 2001). Ideally, vegetative material used for plant propagation should be collected from healthy plants that do not harbor pathogens. If pathogen-free plant material cannot be guaranteed, then procedures may be needed to eliminate or restrict pathogen carryover. Detection methods to screen for pathogens, isolation of newly received plant material, and control treatments have been used for this purpose. HWT is a sanitation method used to reduce pathogen carryover in seeds, tubers, fruits, and vegetables (du Toit and HernandezPerez, 2005; Gramaje et al., 2009; Grondeau and Sampson, 1994; Jarvis, 1992; Keck et al., 1995; Lurie, 2006; Sharma and Tripathi, 2008; Turechek and Peres, 2009). However, thermotherapy techniques have been infrequently reported for use with stem cuttings, probably as a result of the risk of damaging tender shoots and leaves (Jarvis, 1992).

The main purpose of heat treatment is to kill pathogens or insects that infest or infect plant tissue. However, both pathogen and plant genera vary in sensitivity to heat. Therefore, commercial practicality of thermotherapy depends on a large enough difference between the temperature at which a pathogen is killed and the temperature at which plant tissue is damaged. As an example of a moderately acceptable difference, bare-rooted strawberry runners submerged in a $48{ }^{\circ} \mathrm{C}$ bath for $2 \mathrm{~h}$ resulted in up to a $10^{6}$ colony-forming units/ $\mathrm{mL}$ reduction in Xanthomonas fragariae and minimal effect on vegetative growth, whereas submersion in a $52{ }^{\circ} \mathrm{C}$ bath for $60 \mathrm{~min}$ completely killed the bacterium and also killed the plant (Turechek and Peres, 2009). Plant sensitivity to heat may be affected by plant species suitability to climate zones, cultivar response, age of tissue, and moisture content of plant tissue (Baker, 1962; Jarvis, 1992; Lurie, 2006). Additional plant factors influence heat sensitivity of types of plant propagules other than terminal stem cuttings such as external cell tissue type and age of seeds and post-treatment handling of tubers (Baker, 1962; Coyne et al., 2010).

The first objective of the present study was to determine if HWT would damage leaf tissue and/or reduce root development by rooting 12 commonly grown cultivars of evergreen azaleas from different hybrid groups using conventional nursery propagation practices with and without submergence of newly prepared terminal cuttings in $50{ }^{\circ} \mathrm{C}$ water for 20 min. Because 'Gumpo White' azalea cuttings developed only minor leaf tissue damage when submerged in $50{ }^{\circ} \mathrm{C}$ water for 20 to $40 \mathrm{~min}$ and severe leaf damage when submerged in $55^{\circ} \mathrm{C}$ water for $13 \mathrm{~min}$ in our prior study (Copes and Blythe, 2009), the lower $50{ }^{\circ} \mathrm{C}$ water temperature was selected for the current study. The second objective was to evaluate effects of $50^{\circ} \mathrm{C}$ water treatment on terminal cuttings of the same 12 azalea cultivars when submerged for 20 to $80 \mathrm{~min}$ to determine the risk of damage if cuttings are accidentally submerged for longer than the recommended $20 \mathrm{~min}$. Finally, because little is known about the rooting response of azalea after different types of tissue damage, the third objective was to evaluate root development and subsequent leaf production on cuttings of two cultivars in response to incremental reductions in photosynthetic leaf area resulting from either heat-induced leaf tissue damage or leaf removal.

\section{Materials and Methods}

Plant material. Containerized plants of 12 evergreen azalea cultivars (Table 1) were obtained from commercial wholesale nurseries on 7 May 2009 and maintained under 
Table 1. Evergreen azaleas used in three experiments examining responses of cuttings to hot water treatments along with the length of terminal cuttings used for each cultivar.

\begin{tabular}{lllc}
\hline Cultivar name & Trademark name & Hybrid group & Cutting length $(\mathrm{cm})^{\mathrm{y}}$ \\
\hline Conleb & Autumn Embers & Encore & 4.0 \\
Fashion & & Glenn Dale & 4.0 \\
Formosa & & Southern Indica & 6.0 \\
Gumpo White & & Satsuki & 3.5 \\
Hardy Gardenia & & Linwood & 4.0 \\
Hershey Red & & Kurume & 4.5 \\
Macrantha Pink & & Indicum & 5.0 \\
Midnight Flair & & Harris & 5.0 \\
Red Ruffles & & Rutherford & 5.0 \\
Renee Michele & Autumn Debutante & Girard & 4.0 \\
Roblel & Encore & 4.0 \\
Watchet & & Robin Hill & 4.0 \\
\hline
\end{tabular}

${ }^{\mathrm{z}}$ Azalea Society of America. 2007. Azalea index. 17 Aug. 2010. <http://www.azaleas.org/azxintro.html>. ${ }^{y}$ Base of cutting to shoot tip.

overhead irrigation at the Thad Cochran Southern Horticultural Laboratory, Poplarville, MS. On 29 May 2009, stems of the current season's growth were assessed to be suitable for preparation of cuttings. On this date, stems of nine of the cultivars were fully firm (but still green), stems of 'Red Ruffles' were slightly more pliable, and stems of 'Gumpo White' and 'Macrantha Pink' were still moderately pliable. Cutting propagation material was collected during morning hours, placed in zip-lock bags, and put on ice in an insulated cooler. Terminal stem cuttings were prepared to a length appropriate to the cultivar (Table 1) and the leaf removed from the lowest node. Cuttings did not receive any auxin treatment.

Expt. 1. Cuttings of the 12 azalea cultivars were collected and prepared from 2 June to 4 June 2009. Each replication (block) involved submerging or not submerging cuttings in $50{ }^{\circ} \mathrm{C}$ water for $20 \mathrm{~min}$ in a $19-\mathrm{L}$ circulating water bath (Model 260; Precision-NAPCO, a Division of Joshua, Inc., Winchester, VA) with all cultivars being treated at the same time. Three stems (subsamples) of each cultivar were inserted into individual $50-\mathrm{mL}$ plastic tubes attached in a test tube rack submerged in hot water. The plastic tubes had been modified with four offset $1-\mathrm{cm}$ holes to allow water flow through the tubes. Each of the three HWT stems and non-treated stems per replication were randomly inserted in one of six cells in a single column of a 72-cell plug tray containing a peat and pine bark substrate (Fafard 2B; Conrad Fafard, Agawam, MA). The experimental design was a randomized complete block with 12 replications per cultivar and one cultivar per plug tray. The 12 cultivars were individually used in separate sub-experiments to examine response effects across cultivars, but cultivar was not used as an experimental factor for direct comparisons among cultivars. Trays with cuttings were placed on a greenhouse bench under a 6-s mist at 15-min intervals from $0700 \mathrm{HR}$ to $1900 \mathrm{HR}$. Leaves were rated for initial leaf damage on 4 June 2009. Cuttings were removed from the mist and assessed for final leaf damage and root development on 12 Aug. 2009.

Initial leaf damage was rated using the following categories: 0 : no apparent damage, 1 : less than $50 \%$ of leaves exhibit minor discoloration, 2: greater than $50 \%$ of leaves ex- hibit minor discoloration and one to two leaves may have major damage, 3: from 3\% to less than $50 \%$ of leaves exhibit major damage, and 4: greater than $50 \%$ of leaves exhibit major damage. Root development was assessed on a proportional scale: 10 (roots fully cover the vertical surface of the substrate plug), 8.5 (roots cover most of the vertical surface of the substrate plug, but a portion is not covered), 6.0 (many roots incompletely cover the vertical surface of the substrate plug such that some substrate may fall away when the plug is removed from the tray), 4.5 (several, but few, roots incompletely cover the vertical surface of the substrate plug such that some substrate easily falls away when the plug is removed from the tray), 2.0 (several roots are growing in the substrate but few are present on the vertical surface of the substrate plug), and 0.5 (one or two roots extend from the stem into the substrate, but no roots are present on the vertical surface of the substrate plug).

Expt. 2. Terminal cuttings were collected, prepared, and treated from 24 June 2009 to 29 June 2009. Each replication (block) involved submerging cuttings in $50{ }^{\circ} \mathrm{C}$ water (Model 260; Precision-NAPCO) for $20,40,60$, or 80 min with stems of all cultivars being treated at the same time per replication as in Expt. 1. A replication consisted of four cuttings (one per treatment duration) per plastic tube per cultivar with one cutting per cultivar removed every $20 \mathrm{~min}$. The HWT cuttings were inserted into a peat and pine bark substrate (Fafard 2B; Conrad Fafard) in 72-cell plug trays. The experimental design was a randomized complete block with cuttings submerged for the four durations being randomized in a single tray column with 12 replications and one cultivar per tray. Like in Expt. 1, the 12 cultivars were individually used in separate sub-experiments to examine response effects across cultivars, but cultivar was not used as an experimental factor for direct comparisons among cultivars. Cuttings were misted as described previously. The intermittent mist was discontinued and a daily 10 -min irrigation at $1100 \mathrm{HR}$ was begun on 10 Aug.

Initial leaf damage from the HWT was evaluated on 30 June using the proportional leaf damage rating of individual leaves per cutting divided by the total number of leaves (Copes and Blythe, 2009). Between 24 Aug. and 27 Aug., cuttings were evaluated for total leaves per cutting and root development as described in Expt. 1.

Expt. 3. Terminal cuttings of 'Gumpo White' and 'Roblel' were collected, prepared, and treated from 10 June to 18 June 2009. Cuttings of both cultivars were submerged in 55 to $60{ }^{\circ} \mathrm{C}$ water for 7 to $43 \mathrm{~min}$. Cuttings were temporarily inserted into a peat and pine bark substrate (Fafard 2B; Conrad Fafard) in $25.4 \times 25.4-\mathrm{cm}$ trays and placed under intermittent mist to allow development of the initial leaf damage from HWT. Between 15 June and 24 June, leaves were assessed for precision to $25 \%, 50 \%, 75 \%$, and $100 \%$ leaf area damage per cutting and cuttings with respective levels of damage were transferred to columns of 72-cell plug trays as described subsequently using the same substrate.

Additional cuttings with comparable reductions in photosynthetic leaf area (but without HWT) were prepared by removing leaves between 16 June and 18 June. Cuttings of 'Roblel' azalea each had approximately eight leaves of uniform size, so $0 \%, 25 \%$, $50 \%, 75 \%$, and $100 \%$ leaf area removal was achieved by retaining eight, six, four, two, and zero leaves, respectively, per cutting. 'Gumpo White' azalea cuttings had small, medium, and large leaves with a mean area of 48,73 , and $210 \mathrm{~mm}^{2}$, respectively. For 'Gumpo White' cuttings, $0 \%, 25 \%, 50 \%, 75 \%$, and $100 \%$ leaf area removal was achieved by retaining sets of $(8,2,3),(6,2,2),(5,2,1),(4,1,0)$, and $(0,0,0)$ (small, medium, large) leaves, respectively, per stem cutting. Cuttings with each of the five degrees of damage were aligned by type of damage (hot water or leaf removal) in a single tray column with two subsamples from each type of damage randomized in four columns at one end of a tray. Cultivar placement was randomized at one end of each of 12 trays. The experimental design was a complete randomized block with 12 replications. Cuttings were misted as described previously. The intermittent mist was discontinued and a daily 10-min irrigation at $1100 \mathrm{HR}$ was begun on $10 \mathrm{Aug}$. Stem cuttings were assessed for total leaves per cutting and root development between 31 Aug. and 2 Sept. 2009. Root development was evaluated as described in Expt. 1.

Statistical analysis. No or minimal leaf damage was observed in Expt. 1 with almost all cuttings receiving ratings of 0 or 1 ; therefore, Fisher's exact test (lower-tailed) was used to test for limited leaf damage with use of heat treatment (alternative hypothesis) using the FREQ procedure of SAS (Version 9.2; SAS Institute, Cary, NC). Otherwise, root development, initial leaf damage, and final leaf count were analyzed with mixedmodel analysis of variance using the MIXED procedure of SAS. Blocks (replications) were included in the analysis as a random factor. Homogeneity of variance was evaluated by examining box plots of response values and by computing a common variance, individual factor variances, and grouped variances. Variances of individual treatments were generated using the REPEATED statement with 
the GROUP=TREATMENT option. When unequal variances were evident, treatments with similar variances were grouped using a dummy variable and group variances specified with a GROUP=<dummy_variable $>$ statement. The model that best fit the data was selected based on a significant reduction in the difference between the residual $\log$ likelihood values being larger than the $\chi^{2}$ percentage and in the difference between Akaike's Information Criterion values. Least square means and pairwise differences adjusted for multiple comparison were computed for a heteroscedastic model that accounts for non-constant denominator degrees of freedom (Satterthwaite method) by specifying the ADJUST=SMM (studentized maximum modulus) and $\mathrm{ADJDFE}=\mathrm{ROW}$ options.

\section{Results}

Expt. 1. Cuttings of 11 of the 12 cultivars exhibited no significant leaf tissue damage after submersion in $50{ }^{\circ} \mathrm{C}$ water for $20 \mathrm{~min}$ compared with nontreated cuttings (Table 2). Cuttings of 'Macrantha Pink' were damaged by submersion in $50{ }^{\circ} \mathrm{C}$ water, although the level of damage was considered minor. Fashion was the only cultivar with less root growth on cuttings receiving the $50{ }^{\circ} \mathrm{C}$ water treatment compared with nontreated cuttings, but the difference was small such that the root systems likely would have been comparable with a few more weeks of growth (Table 2). Interestingly, a small but significant increase in root development occurred on cuttings of 'Conleb' receiving the $50{ }^{\circ} \mathrm{C}$ water treatment compared with nontreated cuttings.

Expt. 2. Ten cultivars had mean initial leaf damage less than 0.08 with 20 -min submersion in $50{ }^{\circ} \mathrm{C}$ water (Table 3 ). No cultivars

Table 2. Number of terminal cuttings of 12 azalea cultivars exhibiting no leaf damage $2 \mathrm{~d}$ after no treatment or submergence in $50{ }^{\circ} \mathrm{C}$ water for $20 \mathrm{~min}$ and insertion into a pine bark/peat medium in plug trays placed under intermittent mist and mean rating of root development on the same cuttings after a rooting period of 10 weeks $(n=36)($ Expt. 1).

\begin{tabular}{lcccccccc}
\hline & \multicolumn{2}{c}{ Cuttings without leaf damage $(\text { no. })^{\mathrm{z}}$} & & \multicolumn{3}{c}{ Root development $^{\mathrm{y}}$} \\
\cline { 2 - 4 } Cultivar $^{\mathrm{x}}$ & Nontreated & $50^{\circ} \mathrm{C}$ water & Prob. $^{\mathrm{w}}$ & & Nontreated & $50{ }^{\circ} \mathrm{C}$ water & Prob. $^{\mathrm{v}}$ \\
\hline Conleb & 36 & 35 & 0.5000 & & 9.71 & 9.96 & 0.0241 \\
Fashion & 35 & 32 & 0.1785 & & 9.67 & 8.96 & 0.0115 \\
Formosa & 32 & 31 & 0.5000 & & 9.79 & 9.92 & 0.2836 \\
Gumpo White & 36 & 34 & 0.2465 & & 9.96 & 9.92 & 0.5618 \\
Hardy Gardenia & 33 & 30 & 0.2391 & & 10.00 & 10.00 & 1.0000 \\
Hershey Red & 36 & 33 & 0.1197 & & 8.10 & 8.53 & 0.1987 \\
Macrantha Pink & 35 & 20 & $<0.0001$ & & 9.96 & 9.78 & 0.2641 \\
Midnight Flair & 35 & 31 & 0.0993 & & 9.83 & 10.00 & 0.1039 \\
Red Ruffles & 35 & 31 & 0.0993 & & 9.88 & 9.96 & 0.3102 \\
Renee Michele & 33 & 29 & 0.1535 & & 9.96 & 9.85 & 0.3760 \\
Roblel & 33 & 36 & 1.0000 & & 9.91 & 10.00 & 0.1558 \\
Watchet & 31 & 29 & 0.3765 & & 9.85 & 9.81 & 0.7993 \\
\hline
\end{tabular}

${ }^{2}$ Count of cuttings that appeared healthy and exhibited no symptoms of leaf tissue damage. Leaf tissue damage was considered minor on cuttings exhibiting leaf damage.

${ }^{y}$ Root development was assessed on a scale of 0 (no roots) to 10 (extensive root development). No cuttings produced small root systems or failed to root.

${ }^{x}$ Each azalea cultivar was in a separate sub-experiment, whereas treatments were assigned to stem cuttings of each cultivar using a randomized complete block design in a 72-cell tray.

${ }^{\text {w }} P$ values for tests of an increase in leaf damage using heat treatment (alternative hypothesis) based on Fisher's exact test (lower-tailed).

${ }^{\mathrm{v}} P$ values testing the null hypothesis of no difference in root development between nontreated cuttings and cuttings receiving hot water treatment from mixed model analysis of variance for treatments with heterogeneous variances.
(Table 3) than in Expt. 1 (Table 2). Root development on cuttings of eight cultivars was roughly comparable in the two experiments. Cuttings of 'Red Ruffles', 'Macrantha Pink', 'Hardy Gardenia', and 'Hershey Red' had poorer root development in Expt. 2 than in Expt. 1. Initial leaf damage from a 20-min submersion was comparable for 10 cultivars between the two experiments. Cuttings of 'Macrantha Pink' exhibited moderate damage in both experiments, and cuttings of 'Formosa' had moderate leaf damage only in Expt. 2.

Expt. 3. Root development generally decreased with increasing percentage of induced leaf damage (Table 4). Despite this general trend, cuttings of 'Roblel' and 'Gumpo White' responded differently to the increasing percentage of leaf damage induced from submersion in hot water $(P=0.0066)$ and by leaf removal $(P<0.0001)$. 'Roblel' was more tolerant to a moderate degree of leaf damage. With both cultivars, leaf damage resulting from hot water treatment more severely impacted rooting than leaf removal. Generally, incremental increases in hot water-induced leaf damage were associated with incremental decreases in final leaf count and root development, whereas $75 \%$ of the leaf area had to be removed before causing a decline in the final leaf count and root development with both cultivars. Not unexpectedly, a 100\% reduction in photosynthetic leaf area either from hot water-induced leaf damage or from leaf removal resulted in either poor root development and low leaf counts or death of the cutting with both cultivars.

\section{Discussion}

All 12 azalea cultivars were tolerant of a 20 -min submersion in $50{ }^{\circ} \mathrm{C}$ water. In a few cases ['Fashion' in Expt. 1 (Table 2); 'Fashion', 'Gumpo White', 'Macrantha Pink', and 'Red Ruffles' in Expt. 2 (Table 3)], the $50{ }^{\circ} \mathrm{C}$ water treatment slowed root development such that the cuttings would require additional weeks of root growth beyond the 9- to 10 -week period used in these experiments before transplanting.

Differences in cultivar sensitivity to hot water were evident with extended submersion duration in $50{ }^{\circ} \mathrm{C}$ water. Root development did not differ between the 20-min and 40-min submersion for all 12 cultivars, although final leaf count was reduced with a 40-min submersion for two cultivars. These results support previous results (Copes and Blythe, 2009) when leaf tissue of 'Gumpo White' azalea stem cuttings were not severely damaged in $50{ }^{\circ} \mathrm{C}$ water for $40 \mathrm{~min}$. The difference in cultivar sensitivity occurred when stem cuttings were submerged for 60 to 80 min. In the present study, the mean final leaf count and root development of four cultivars (Conleb, Gumpo White, Renee Michelle, and Roblel) were unaffected by increased submersion in hot water from $20 \mathrm{~min}$ to $80 \mathrm{~min}$. These responses were mostly associated with low levels of initial leaf damage. We thus consider these cultivars to be tolerant of $50{ }^{\circ} \mathrm{C}$ 
Table 3. Mean initial leaf damage ratings on terminal cuttings of 12 azalea cultivars $2 \mathrm{~d}$ after no treatment or submergence in $50^{\circ} \mathrm{C}$ water for 20 to $80 \mathrm{~min}$ and final leaf count and degree of root development on the same cuttings after a rooting period of 9 weeks $(n=12)($ Expt. 2) with cultivars ordered by similar response groupings.

\begin{tabular}{|c|c|c|c|c|c|c|}
\hline \multirow[b]{2}{*}{ Cultivar } & \multirow[b]{2}{*}{ Response variable } & \multicolumn{4}{|c|}{ Duration of submersion (min) } & \multirow[b]{2}{*}{ Prob. $^{z}$} \\
\hline & & 20 & 40 & 60 & 80 & \\
\hline \multirow[t]{3}{*}{ Roblel } & Initial leaf damage $^{y}$ & $0.0 \mathrm{a}^{\mathrm{x}}$ & $0.03 \mathrm{a}$ & $0.08 \mathrm{a}$ & $0.16 \mathrm{~b}$ & 0.0002 \\
\hline & Final leaf count & 15.8 & 21.0 & 19.1 & 19.9 & 0.1860 \\
\hline & Root development ${ }^{\mathrm{w}}$ & 9.9 & 9.9 & 10.0 & 9.5 & 0.2415 \\
\hline \multirow[t]{3}{*}{ Conleb } & Initial leaf damage & $0.02 \mathrm{a}$ & $0.03 \mathrm{a}$ & $0.24 \mathrm{~b}$ & $0.28 \mathrm{~b}$ & 0.0002 \\
\hline & Final leaf count & 10.2 & 10.0 & 9.1 & 8.0 & 0.4485 \\
\hline & Root development & 9.2 & 9.5 & 8.5 & 8.4 & 0.4712 \\
\hline \multirow[t]{3}{*}{ Gumpo White } & Initial leaf damage & $0.01 \mathrm{a}^{\mathrm{c}}$ & $0.02 \mathrm{ab}$ & $0.04 \mathrm{ab}$ & $0.07 \mathrm{~b}$ & 0.0004 \\
\hline & Final leaf count & 20.8 & 24.2 & 24.0 & 22.8 & 0.2899 \\
\hline & Root development & 7.4 & 7.4 & 6.7 & 6.7 & 0.5709 \\
\hline \multirow[t]{3}{*}{ Renee Michelle } & Initial leaf damage & $0.03 \mathrm{a}$ & $0.13 \mathrm{ab}$ & $0.29 \mathrm{~b}$ & $0.35 \mathrm{~b}$ & $<0.0001$ \\
\hline & Final leaf count & 16.0 & 18.2 & 15.6 & 13.7 & 0.4009 \\
\hline & Root development & 8.0 & 8.0 & 6.0 & 5.7 & 0.1010 \\
\hline \multirow[t]{3}{*}{ Watchet } & Initial leaf damage & $0.04 \mathrm{a}$ & $0.08 \mathrm{a}$ & $0.17 \mathrm{ab}$ & $0.36 \mathrm{~b}$ & 0.0010 \\
\hline & Final leaf count & $11.7 \mathrm{a}$ & $17.3 \mathrm{a}$ & $10.3 \mathrm{ab}$ & $3.6 \mathrm{~b}$ & 0.0004 \\
\hline & Root development & $9.4 \mathrm{a}$ & $8.5 \mathrm{ab}$ & $6.5 \mathrm{bc}$ & $4.3 \mathrm{c}$ & 0.0012 \\
\hline \multirow[t]{3}{*}{ Red Ruffles } & Initial leaf damage & $0.02 \mathrm{a}$ & $0.23 \mathrm{ab}$ & $0.44 \mathrm{~b}$ & $0.52 \mathrm{~b}$ & $<0.0001$ \\
\hline & Final leaf count & $16.3 \mathrm{ab}$ & $16.6 \mathrm{a}$ & $12.4 \mathrm{ab}$ & $8.8 \mathrm{~b}$ & 0.0311 \\
\hline & Root development & $6.1 \mathrm{a}$ & $5.7 \mathrm{a}$ & $4.3 \mathrm{ab}$ & $2.4 \mathrm{~b}$ & 0.0131 \\
\hline \multirow[t]{3}{*}{ Midnight Flair } & Initial leaf damage & $0.07 \mathrm{a}$ & $0.27 \mathrm{~b}$ & $0.46 \mathrm{bc}$ & $0.55 \mathrm{c}$ & $<0.0001$ \\
\hline & Final leaf count & $21.7 \mathrm{a}$ & $19.2 \mathrm{ab}$ & $10.1 \mathrm{bc}$ & $3.9 \mathrm{c}$ & $<0.0001$ \\
\hline & Root development & $10.0 \mathrm{a}$ & $7.5 \mathrm{a}$ & $3.4 \mathrm{~b}$ & $1.8 \mathrm{~b}$ & $<0.0001$ \\
\hline \multirow[t]{3}{*}{ Fashion } & Initial leaf damage & $0.02 \mathrm{a}$ & $0.08 \mathrm{a}$ & $0.34 \mathrm{~b}$ & $0.60 \mathrm{c}$ & $<0.0001$ \\
\hline & Final leaf count & $13.8 \mathrm{ab}$ & $17.8 \mathrm{a}$ & $12.3 \mathrm{~b}$ & $1.7 \mathrm{c}$ & $<0.0001$ \\
\hline & Root development & $7.9 \mathrm{a}$ & $7.2 \mathrm{a}$ & $5.1 \mathrm{a}$ & $1.0 \mathrm{~b}$ & $<0.0001$ \\
\hline \multirow[t]{3}{*}{ Formosa } & Initial leaf damage & $0.28 \mathrm{a}$ & $0.54 \mathrm{~b}$ & $0.65 \mathrm{bc}$ & $0.71 \mathrm{c}$ & $<0.0001$ \\
\hline & Final leaf count & $12.4 \mathrm{a}$ & $6.8 \mathrm{~b}$ & $4.6 \mathrm{bc}$ & $1.3 \mathrm{c}$ & $<0.0001$ \\
\hline & Root development & $9.0 \mathrm{a}$ & $6.4 \mathrm{a}$ & $5.1 \mathrm{ab}$ & $1.2 \mathrm{~b}$ & $<0.0001$ \\
\hline \multirow[t]{3}{*}{ Macrantha Pink } & Initial leaf damage & $0.11 \mathrm{a}$ & $0.37 \mathrm{~b}$ & $0.54 \mathrm{bc}$ & $0.62 \mathrm{c}$ & $<0.0001$ \\
\hline & Final leaf count & $14.8 \mathrm{ab}$ & $17.2 \mathrm{a}$ & $5.3 \mathrm{bc}$ & $1.2 \mathrm{c}$ & $<0.0001$ \\
\hline & Root development & $5.8 \mathrm{a}$ & $6.0 \mathrm{a}$ & $2.2 \mathrm{ab}$ & $0.8 \mathrm{~b}$ & $<0.0001$ \\
\hline \multirow[t]{3}{*}{ Hardy Gardenia } & Initial leaf damage & $0.02 \mathrm{a}$ & $0.07 \mathrm{ab}$ & $0.12 \mathrm{bc}$ & $0.38 \mathrm{c}$ & 0.0012 \\
\hline & Final leaf count & $7.2 \mathrm{ab}$ & $12.7 \mathrm{a}$ & $7.4 \mathrm{ab}$ & $4.7 \mathrm{~b}$ & 0.0154 \\
\hline & Root development & 4.0 & 4.7 & 3.4 & 2.3 & 0.2961 \\
\hline \multirow[t]{3}{*}{ Hershey Red } & Initial leaf damage & $0.01 \mathrm{a}$ & $0.27 \mathrm{~b}$ & $0.44 \mathrm{~b}$ & $0.52 \mathrm{~b}$ & $<0.0001$ \\
\hline & Final leaf count & $12.0 \mathrm{a}$ & $8.7 \mathrm{~b}$ & $6.4 \mathrm{~b}$ & $6.2 \mathrm{~b}$ & 0.0015 \\
\hline & Root development & 4.4 & 4.7 & 3.9 & 3.2 & 0.5513 \\
\hline
\end{tabular}

zProbability (based on Type III sums of squares) using the MIXED procedure of SAS with heterogenous variances models to test the null hypothesis that all factor levels are equal.

yProportional leaf damage per cutting calculated by [(number of leaves with less than $50 \%$ area damage $\times$ $0.25)+($ number of leaves with greater than $50 \%$ area damage $\times 0.75) /$ total number of leaves].

${ }^{x}$ Based on multiple pairwise comparisons, means followed by the same letter across a row are not significantly different $(\alpha=0.05)$.

${ }^{\text {w}}$ Root development was assessed on a scale of 0 (no roots) to10 (extensive root development).

exposure. The other eight cultivars were sensitive to 60 - to 80 -min submersion in $50{ }^{\circ} \mathrm{C}$ water. Because cuttings of all 12 cultivars were tolerant of $50{ }^{\circ} \mathrm{C}$ water for up to $40 \mathrm{~min}$ and only a 21-min submersion is needed to kill binucleate Rhizoctonia spp. (Copes and Blythe, 2009), a sufficient margin exists to provide a low risk of reducing the rooting potential of treated stem cuttings, even with the cultivars considered to be sensitive to $50{ }^{\circ} \mathrm{C}$ exposure.

Binucleate Rhizoctonia spp. was also eliminated from 'Gumpo White' azalea stem tissue with a 5 -min $19-\mathrm{s}$ submersion in $55^{\circ} \mathrm{C}$ water (Copes and Blythe, 2009). We caution against using an increased water temperature with shorter submersion duration because of the substantially increased risk of tissue damage. Cuttings of 'Gumpo White' azalea (which we consider to be a tolerant cultivar) vars are collected at the appropriate time based on the experience of the propagator. In the present study, cuttings of all cultivars were collected during the same period. Stem tissue of some cultivars such as the laterblooming 'Macrantha Pink' was less firm than other cultivars, and this could have affected rooting success. Rooting can be variable even when cuttings are not submersed in hot water as a result of cultural practices affecting the quality of cuttings. Undoubtedly, hot water has the potential to cause tissue damage although the effect on subsequent rooting and shoot growth is minor.

Based on published (but limited) research, pathogens vary in their sensitivity to thermotherapy (Baker, 1962; Baker and Roistacher, 1972; du Toit and Hernandez-Perez, 2005; Gramaje et al., 2009; Grondeau and Sampson, 1994; Jarvis, 1992; Keck et al., 1995; Sharma and Tripathi, 2008; Turechek and Peres, 2009). A few pathogens, including propagules of Pythium and Phytophthora, may be detrimentally affected by exposure to $50{ }^{\circ} \mathrm{C}$ water (Baker and Roistacher, 1972). Many other pathogens may survive exposure to $50{ }^{\circ} \mathrm{C}$ for $21 \mathrm{~min}$ and therefore would require a hotter temperature or longer exposure before being physiologically stressed. The depth of pathogen penetration into plant tissue and the type of pathogen structure such as oospores of Phytophthora spp. could affect pathogen survival. Thermotherapy such as hot water submersion is capable of causing mortality of pathogens within plant tissue that might otherwise be unaffected by many chemical treatments. Additional research would be needed to identify which pathogens can be killed by thermotherapy without detrimental injury to cuttings.

Water bath equipment does exist for applying hot water treatments. The main requirements involve properly grounded and waterproofed electrical systems, a heater with precise water temperature regulation (a variation of $0.3{ }^{\circ} \mathrm{C}$ or less), ample water circulation (needed to achieve uniform temperature distribution), and a sufficient water volume to limit the drop in water temperature to only a few degrees when cuttings are submersed. Plant material should be loosely contained in a meshed container that is smaller than the water depth and tank dimensions so that plant material is completely submersed and water flow is unimpeded. The water volume capacity of a hot water bath would depend on the maximum number and size of propagules being submersed together. If only cuttings are being treated, 40- to 100-L tanks would suffice for many commercial nurseries. Analog controllers would be less expensive than digital controllers.

HWT provides an alternative and effective disease control method for eliminating Rhizoctonia spp. from azalea cuttings. Initial costs would be incurred by purchasing and installing the hot water bath. Additional production costs would include power use of the equipment for several hours per day and assignment of an employee to the task. Additional benefits are unknown, but hot water 
Table 4. Mean leaf count and root development on cuttings of two azalea cultivars in response to selected percentage levels of induced leaf damage resulting from either hot water treatment or physical leaf removal after a rooting period of 10 weeks $(n=12)($ Expt. 3$)$.

\begin{tabular}{|c|c|c|c|c|c|}
\hline \multirow[b]{2}{*}{$\begin{array}{l}\text { Leaf damage } \\
\text { type }\end{array}$} & \multirow[b]{2}{*}{$\begin{array}{l}\text { Induced leaf } \\
\text { damage }(\%)^{z}\end{array}$} & \multicolumn{2}{|c|}{ Gumpo White } & \multicolumn{2}{|c|}{ Roblel } \\
\hline & & $\begin{array}{c}\text { Leaves } \\
\text { (no.) }\end{array}$ & $\begin{array}{c}\text { Root } \\
\text { development }\end{array}$ & $\begin{array}{c}\text { Leaves } \\
\text { (no.) }\end{array}$ & $\begin{array}{c}\text { Root } \\
\text { development }\end{array}$ \\
\hline \multirow[t]{5}{*}{$50^{\circ} \mathrm{C}$ water } & 0 & $18.0 \mathrm{a}^{\mathrm{x}}$ & $7.8 \mathrm{a}$ & $13.9 \mathrm{ab}$ & $9.9 \mathrm{a}$ \\
\hline & 25 & $15.3 \mathrm{ab}$ & $4.9 \mathrm{~b}$ & $17.8 \mathrm{~b}$ & $9.8 \mathrm{a}$ \\
\hline & 50 & $8.6 \mathrm{c}$ & $2.6 \mathrm{bc}$ & $10.8 \mathrm{a}$ & $6.7 \mathrm{~b}$ \\
\hline & 75 & $0.6 \mathrm{~d}$ & $0.6 \mathrm{c}$ & $8.5 \mathrm{a}$ & $4.0 \mathrm{~b}$ \\
\hline & 100 & $0.0 \mathrm{~d}$ & $0.5 \mathrm{c}$ & $0.0 \mathrm{c}$ & $0.5 \mathrm{c}$ \\
\hline \multirow[t]{5}{*}{ Leaf removal } & 0 & $20.2 \mathrm{a}$ & $8.9 \mathrm{a}$ & $11.3 \mathrm{a}$ & $9.4 \mathrm{a}$ \\
\hline & 25 & $18.5 \mathrm{a}$ & $8.1 \mathrm{a}$ & $11.2 \mathrm{a}$ & $8.9 \mathrm{ab}$ \\
\hline & 50 & $15.5 \mathrm{ab}$ & $8.2 \mathrm{a}$ & $11.0 \mathrm{a}$ & $9.0 \mathrm{ab}$ \\
\hline & 75 & $12.8 \mathrm{~b}$ & $4.9 \mathrm{~b}$ & $10.5 \mathrm{a}$ & $6.7 \mathrm{~b}$ \\
\hline & 100 & $0.0 \mathrm{~d}$ & $0.5 \mathrm{c}$ & $0.4 \mathrm{c}$ & $0.6 \mathrm{c}$ \\
\hline \multicolumn{2}{|c|}{ Damage type (typ) $\operatorname{Pr}>F^{w}$} & $<0.0001$ & $<0.0001$ & 0.0621 & 0.0145 \\
\hline \multicolumn{2}{|c|}{ Leaf damage (dmg) $\mathrm{Pr}>\mathrm{F}$} & $<0.0001$ & $<0.0001$ & $<0.0001$ & $<0.0001$ \\
\hline \multicolumn{2}{|c|}{ typ $\times$ dmg interaction $\operatorname{Pr}>F$} & $<0.0001$ & $<0.0001$ & 0.0014 & 0.0026 \\
\hline
\end{tabular}

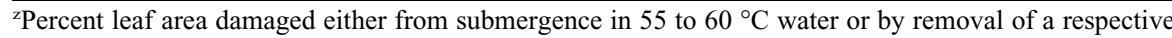
number of leaves representing an equivalent leaf area.

${ }^{y}$ Root development was assessed on a scale of 0 (no roots) to10 (extensive root development).

${ }^{x}$ Based on multiple pairwise comparisons, means followed by the same letter down a column are not significantly different $(\alpha=0.05)$.

wProbability (based on Type III sums of squares) using the MIXED procedure of SAS with heterogeneous variances models to test the null hypothesis that all factor levels are equal.

potentially could control other organisms such as insect pests (Haviland et al., 2005; Stonerod and Strik, 1996). Hot water is a certified disease and pest control treatment in some state regulatory programs. Thermotherapy provides an example of how simple techniques may provide effective disease control when appropriately applied. Integrated disease management merits more research effort to develop potential benefits to the labor-intensive management systems associated with ornamental plant production.

\section{Literature Cited}

Baker, K.F. 1962. Thermotherapy in planting material. Phytopathology 52:1244-1255.
Baker, K.F. and C.N. Roistacher. 1972. Heat treatment of soil, p. 123-137. In: Baker, K.F (ed.). The U.C. system for producing healthy container-grown plants. Calif. Agr. Exp. Sta. Manual 23. University of California Division of Agricultural Sciences, Berkeley, CA. hot water treatments to control Rhizoctonia $\mathrm{AG}$ $\mathrm{P}$ infesting stem cuttings of azalea. HortScience 44:1370-1376.

Coyne, D.L., A.O. Claudius-Cole, L. Kenyon, and H. Baimey. 2010. Differential effect of hot water treatment on whole tubers versus cut sets of yam (Dioscorea spp.). Pest Manag. Sci. 66:385-389.

Daughtrey, M.L. and D.M. Benson. 2005. Principles of plant health management for ornamental plants. Annu. Rev. Phytopathol. 43:141-169.
Copes, W.E. and E.K. Blythe. 2009. Chemical and du Toit, L.J. and P. Hernandez-Perez. 2005. Efficacy of hot water and chlorine for eradication of Cladosporium variabile, Stemphylium botryosum, and Verticillium dahliae from spinach seed. Plant Dis. 89:1305-1312.

Gramaje, D., J. Armengol, D. Salazar, I. LópezCortés, and J. García-Jiménez. 2009. Effect of hot-water treatments above $50{ }^{\circ} \mathrm{C}$ on grapevine viability and survival of Petri disease pathogens. Crop Prot. 28:280-285.

Grondeau, C. and R. Sampson. 1994. A review of thermotherapy to free plant materials from pathogens, especially seeds from bacteria. Crit. Rev. Plant Sci. 13:57-75.

Haviland, D.R., W.J. Bentley, and K.M. Daane. 2005. Hot-water treatments for control of Planococcus ficus (Homoptera: Pseudococcidae) on dormant grape cuttings. J. Econ. Entomol. 98: $1109-1115$.

Jarvis, W.R. 1992. Thermotherapy, p. 112-115. In: Jarvis, W.R. (ed.). Managing diseases in greenhouse crops. APS Press, St. Paul, MN.

Keck, M., R. Chartier, W. Zislavsky, P. Lecomte, and J.P. Paulin. 1995. Heat treatment of plant propagation material for the control of fire blight. Plant Pathol. 44:124-129.

Lurie, S. 2006. The effect of high temperature treatment on quality of fruits and vegetables. Acta Hort. 712:785-792.

Sharma, N. and A. Tripathi. 2008. Integrated management of postharvest Fusarium rot of gladiolus corms using hot water, UV-C and Hyptis suaveolens (L.) Poit. essential oil. Postharvest Biol. Technol. 47:246-254.

Stonerod, P. and B. Strik. 1996. Hot-water dipping eradicates phylloxera from grape nursery stock. HortTechnology 6:381-388.

Turechek, W.W. and N.A. Peres. 2009. Heat treatment effects on strawberry plant survival and angular leaf spot, caused by Xanthomonas fragariae, in nursery production. Plant Dis. 93: 299-308.

Williams-Woodward, J. and R.K. Jones. 2001. Sanitation: Plant health from start to finish, p. 384-386. In: Jones, R.K. and D.M. Benson (eds.). Diseases of woody ornamentals and trees in nurseries. APS Press, St. Paul, MN. 